\title{
Effect of Exogenous Melatonin Treatment on the Reproductive Characteristics and Progeny of Male Rats Exposed to Different Periods From Light and Darkness
}

\author{
K. A. A. MAJRASHI ${ }^{1,2}$, I. A. H. BARAKAT ${ }^{1,3}$, A. R. AL-HIMAIDI ${ }^{1}$, K. G. ADHAM ${ }^{1,4}$ \\ ${ }^{1}$ Zoology Department, College of Science, King Saud University, Riyadh, Saudi Arabia, ${ }^{2}$ Biology \\ Department, College of Science, King Abdul-Aziz University, Rabigh, Saudi Arabia, ${ }^{3}$ Department \\ of Cell Biology, National Research Center, Dokki, Giza, Egypt, ${ }^{4}$ Zoology Department, Faculty of \\ Science, Alexandria University, Alexandria, Egypt
}

Received November 17, 2016

Accepted February 7, 2017

On-line February 28, 2017

\section{Summary}

Light is an important environmental factor that controls the regulation of physiological functions of organisms. Melatonin is considered as one of the major hormones that play an important role in protecting body from many harmful effects and acts as a powerful anti-oxidant source to controlling the levels of antioxidant enzymes within the body. The main objectives of this work were to study the effect of 1 ) photoperiod changes and 2) exogenous melatonin hormone treatment on the sperm properties, body and testis weight, embryo characteristics, and concentration level of melatonin and testosterone in treated rat serum. This study has been conducted using thirty-six male rats and one hundred and twenty female rats. Animals were divided into six groups, each group containing six males and twenty female rats. Our results showed a significant influence of photoperiod changes on the melatonin and testosterone hormones concentration in rats' serum, body weight only, while the other characteristics not affected. As for the effect of melatonin it has been found that the movement of sperm in GIII and IV, as well as embryos absorbed and newborns weight traits has been significantly affected, while the rest of the properties were not significantly affected by melatonin treatment.

\section{Key words}

Melatonin • Photoperiod $\bullet$ Embryo $\bullet$ Sperm properties

\section{Corresponding author}

I. A. H. Barakat, Zoology Department, College of Science, King Saud University, P.O. Box 2455, Riyadh 11451, Saudi Arabia. Fax:
009661-4678514. E-mail: ibarakat@ksu.edu.sa or ibrahimahb@yahoo.com

\section{Introduction}

Light and photoperiod changes from one season to another are considered as important environmental factors that affect the physiological processes in the animal, including the production of hormones and sperm by influencing the hypothalamus (Hotzel et al. 2003, Sogorescu et al. 2011, Rani and Kumar 2014).

Semen quality is important in the assessment of male fertility; sperm must be examined for each male where gives the reason for the lack of fertility. Many researchers have examined the relationship between fertility and semen characteristics and daily light cycle and they found conflicting results (Sellés et al. 2003, Popwell and Flowers 2004, Ruiz-Sánchez et al. 2006, Broekhuijse et al. 2012, Petrocelli et al. 2015). Favre et al. (2012) reported that natural photoperiod induces seasonal changes in spermatozoa quality but not in serum testosterone concentrations. Photoperiod changes determine increased secretion of testosterone and testicular volume (Hotzel et al. 2003, Sogorescu et al. 2011, Sogorescu et al. 2012). The response to photoperiod was similar in different animals, such as sheep and goats that show variations in testosterone secretion and semen quality according to changes in long day and then light and darkness hours (Delgadillo and 
Chemineau 1992, Delgadillo et al. 2000, Lebouef et al. 2000, Sogorescu et al. 2011, Sogorescu et al. 2012). The percentage of normal spermatozoa was higher through February to July than during August to January (Axner and Linde 2007). Also, Blottner and Jewgenow (2007) found that there are significant differences between spring and autumn for the sperm count per testis and weight of testis. As mentioned before by Borg et al. (1993) and Kozdrowski and Dubiel (2004) reported that the sperm volume and concentrations were lowest in the spring, gradually increase in the summer and reach to the top values in late autumn season. Therefore, photoperiod changes are involved in regulating the reproductive cycles and are linked with functions in several mammals and avian (Misra et al. 2004, Hazlerigg and Wagner 2006, Dixit and Singh 2011). This is called photoperiodism (Rani and Kumar 2014).

Melatonin has been studied on a large scale during the past decades due to its physiological functions and medical importance. The chemical composition was identified after being isolated from the bovine pineal glands in 1956 (Lerner et al. 1959). Melatonin hormone is called sleep hormone, secreted by the pineal gland with rhythmically and is influenced by environmental photoperiod (Donmez et al. 2004), it is not only produced from mammalian organs and cells, but can be produced from non-mammalian species cells such as bacteria and edible plants (Lerner et al. 1959, Hardeland et al. 1995, Dubbels et al. 1995, Tilden et al. 1997, Stefulj et al. 2001, Rocha et al. 2015). Also, balsamic vinegars and dessert wines as example for grape product were found to contain melatonin (Vitalini et al. 2013). Many functions of melatonin are described in the past decades through numerous researches. Among these reported functions, melatonin has anti-proliferative, anti-inflammatory and apoptotic properties (Perdomo et al. 2013). In addition, a study by Levine et al. (1990) found that count, concentration and motility of men sperm were significantly decreased during the longer days in summer. Peschke et al. (2006) reported important role for melatonin in metabolic deficiencies and glucose regulation. Furthermore, melatonin works to protect the testicular functions and spermatogenesis from many harmful effects of many disorders (Rocha et al. 2015). In addition, the roles of melatonin were attributed to its ability to minimize the oxidative stress by removing nitrogen species, free radicals and control the levels of oxidative enzymes (Hardeland $e t$ al. 1995, Lerner et al. 1959, Espino et al. 2010, Galano et al. 2011, Lampiao and Plessis 2013, Chabra et al. 2014).
Noticeably, data indicated that melatonin administration causes a decrease in seminiferous tubules diameter, inhibition of spermatogenesis and reduction size of Leydig cells (Ooi and Ng 1989, Sogorescu et al. 2012). Many other functions of this hormone are described in the last decades. However, its overall impact on the physiological male reproductive system is still not well known (Rocha et al. 2015). The aim of this study was to determine the effect of photoperiod changes and treated with exogenous melatonin treatment on sperm characteristics, acquired body weight, testicle weight, serum melatonin and testosterone hormone level and embryos properties in groups of male and female rats.

\section{Materials and Methods}

Animals

In this study, thirty-six male (five males only used in mating process for each group) and one hundred twenty females from Albino Wister rat strain were used. Animals were obtained from Faculty of Pharmacy, King Saud University, and their weights ranged from 220 to $250 \mathrm{~g}$ for males and 180 to $200 \mathrm{~g}$ for females and all animal aged was about 12 weeks. Rats have been bred in a special room; temperature was ranging from 22 to $24{ }^{\circ} \mathrm{C}$. Water and feed were introduced ad libitum. Feed was purchased from the general organization for Grain Silos and Flour Mills, Riyadh, Saudi Arabia. The feed used in experiments was composed from $20 \%$ protein, $4 \%$ fat, $3.5 \%$ fiber, $0.6 \%$ phosphorus, $6.0 \%$ ash, $0.5 \%$ sodium chloride, $1.0 \%$ Calcium, 20.0 I.U. vitamin A, 2.2 I.U. vitamin D and 70.0 I.U. vitamins C.

\section{Experimental Design}

Male rats were divided according to exposure to light and darkness cycle for ten weeks (Mukherjee and Haldar 2014) and treatment with melatonin by intraperitoneally injection for 4 weeks (Alabbassi et al. 2008) to 6 groups $(\mathrm{G})$ as shown in Table 1. Group I (GI) was considered as control group for groups III (GIII) and $\mathrm{V}(\mathrm{GV})$ to study the effect of light/darkness cycle. Also, GI, GIII and group V (GV) were considered as control for GII, group IV (GIV) and group VI (GVI), respectively, to study the effect of melatonin.

As for females, they has been maintained under lighting cycle consists of $12 \mathrm{~h}$ light and $12 \mathrm{~h}$ darkness from beginning the experiment until the tenth week for the regulation its reproductive cycle before mating. In the tenth week, four mature females were placed with one male 
from previous each groups in Table 1 for six days to make mating. Insemination was detected daily, the insemination day was considered as a zero day of pregnancy. The fertilized females were divided into two groups; the first group has been sacrificed in the nineteenth day of pregnancy to determine the number of live and absorbed embryos and weights of live embryos. The second group was left until after the birth to determine the number of embryonic implantation and compare it with the number of live newborns, and fetus's weights.

Table 1. Groups of treated and non-treated animals, light/darkness cycle and melatonin injection.

\begin{tabular}{|c|c|c|c|c|c|c|c|}
\hline $\begin{array}{l}\text { Groups (G) } \\
\text { Treatment }\end{array}$ & Treatment Beginning & $\begin{array}{c}\text { GI } \\
\text { Control }\end{array}$ & GII & GIII & GIV & GV & GVI \\
\hline $\begin{array}{l}12 \text { h light/12 h darkness } \\
\text { (Natural photoperiod) }\end{array}$ & First week to Tenth week & $\sqrt{ }$ & $\sqrt{ }$ & - & - & - & - \\
\hline $\begin{array}{l}6 \text { h light/18 h darkness } \\
\text { (Short day) }\end{array}$ & First week to Tenth week & - & - & $\sqrt{ }$ & $\sqrt{ }$ & - & - \\
\hline $\begin{array}{l}18 \text { h light/6 h darkness } \\
\text { (Long day) }\end{array}$ & First week to Tenth week & - & - & - & - & $\sqrt{ }$ & $\sqrt{ }$ \\
\hline $\begin{array}{l}\text { Melatonin } \\
(20 \mathrm{mg} / \mathrm{kg})\end{array}$ & Seventh week for 28 days & - & $\sqrt{ }$ & - & $\sqrt{ }$ & - & $\sqrt{ }$ \\
\hline $\begin{array}{l}\text { Sesame Oil }(0.3-0.4 \mathrm{ml}) \\
\text { (Melatonin solvent) }\end{array}$ & Seventh week for 28 days & $\sqrt{ }$ & - & $\sqrt{ }$ & - & $\sqrt{ }$ & - \\
\hline
\end{tabular}

$\sqrt{ }=$ Treated,$-=$ Non-treated

\section{Melatonin preparation}

Melatonin (Melatonin powder, Sigma, USA, M5250) has been dissolved in pure sesame oil (Goldman 1991), which was obtained from the Plant Oil Kattouf Vallery, Jeddah, Saudi Arabia prior to injection directly. The dose used was prepared by dissolving $1 \mathrm{~g}$ of melatonin in $100 \mathrm{ml}$ of sesame oil to obtain $20 \mathrm{mg} / \mathrm{kg}$ concentration. The volume of dose used was determined by using the following equation:

Volume required $(\mathrm{ml})=$ Dose $(\mathrm{mg} / \mathrm{kg}) \mathrm{X}$ animal weight $(\mathrm{Kg}) /$ Melatonin concentration $(\mathrm{mg} / \mathrm{ml})$

The dose of melatonin was injected between 7 and 8 AM daily.

\section{Experimental measurements}

Testosterone and melatonin assay: Serum testosterone and melatonin were analyzed in blood samples collected at the end of experiment from males using testosterone Elisa Kit (Fisher Scientific, USA) and rat melatonin Elisa kit (Fisher Scientific, USA) respectively, as described in the manufacturer manual kit.

Body weight: The body weight of rats was taken after six weeks from experiment start to study the effect of lighting cycle on body weight and at the end of experiment and treatment with melatonin; the body weight was taken again to study the effect of treatment with melatonin on the body weight.

Testes weight: The testes weight of male rats exposed to lighting cycle and treatment with melatonin was taken at the end of experiment.

Pregnancy rate: The pregnancy rate was calculated by the number of pregnant females at the end of the experiment for each male.

Number and weight of embryos and newborns: The number and weight of embryos was determined after sacrificing pregnant females at nineteenth day of gestation. As for the newborns, the number and weights were taken after the birth.

\section{Sperm collection and analysis}

After treatment throughout the experiment, sperms were collected from all male rats by removed tail epididymis from sacrificed males to assess the motility, total number and live and dead of sperm using semen analyzer IVOS (Hamilton Thorne, USA) (Sharon et al. 2015).

\section{Statistical analysis}

All data was analysis using paired sample t-test and one way analysis of variance (ANOVA). Treatment 
means were compared using Duncan test at $\mathrm{P} \leq 0.05$ significant level. Analyzed data were expressed as mean \pm SE.

\section{Results}

Effect of light/darkness cycle

Lighting cycle had a significant effect $(\mathrm{P} \leq 0.05)$ on the body weight, where the mean value was greatest in the GV $(129.0 \pm 13.8)$ at $18 \mathrm{~h}$ light and lowest in GI $(73.2 \pm 14.5)$ at $12 \mathrm{~h}$ light. On the other hand, it does not have any significant effect on the testes weight (Table 2). Similarly, for characteristics of sperm (Table 3) and embryos, pregnancy rate and implantation sites (Fig. 1), it was found that the photoperiod changes have no significant effect.

Table 2. Effect of light/darkness cycle on the acquired body and testes weight in groups non-treated with melatonin.

\begin{tabular}{lcc}
$\begin{array}{l}\text { Traits } \\
\text { Treatment groups }\end{array}$ & Acquired body weight & Acquired testes weight \\
\hline Group I $(G I)$ & $73.2 \pm 14.5^{\mathrm{a}}$ & $1.77 \pm 0.0$ \\
Group III $(G I I I)$ & $112.8 \pm 8.3^{\mathrm{b}}$ & $1.78 \pm 0.1$ \\
Group $V(G V)$ & $129.0 \pm 13.8^{\mathrm{b}}$ & $1.75 \pm 0.0$ \\
\hline
\end{tabular}

Table 3. Effect of light/darkness cycle on the sperm characteristics in groups non-treated with melatonin.

\begin{tabular}{|c|c|c|c|c|}
\hline $\begin{array}{l}\text { Traits } \\
\text { Treatment groups }\end{array}$ & $\begin{array}{l}\text { Total number of } \\
\text { sperm/ml X } 10^{6}\end{array}$ & $\begin{array}{c}\text { Normal } \\
\text { movement type }\end{array}$ & $\begin{array}{c}\text { Abnormal } \\
\text { movement type }\end{array}$ & Dead sperm \\
\hline Group I (GI) & $1.146 .7 \pm 69.3$ & $309.3 \pm 33.9$ & $478.7 \pm 66.0$ & $326.2 \pm 23.4$ \\
\hline Group III (GIII) & $1.454 .7 \pm 169.0$ & $226.4 \pm 58.3$ & $419.5 \pm 97.4$ & $289.6 \pm 35.4$ \\
\hline Group $V(G V)$ & $1.067 .3 \pm 132.0$ & $286.0 \pm 32.7$ & $345.4 \pm 59.6$ & $318.4 \pm 102.3$ \\
\hline
\end{tabular}

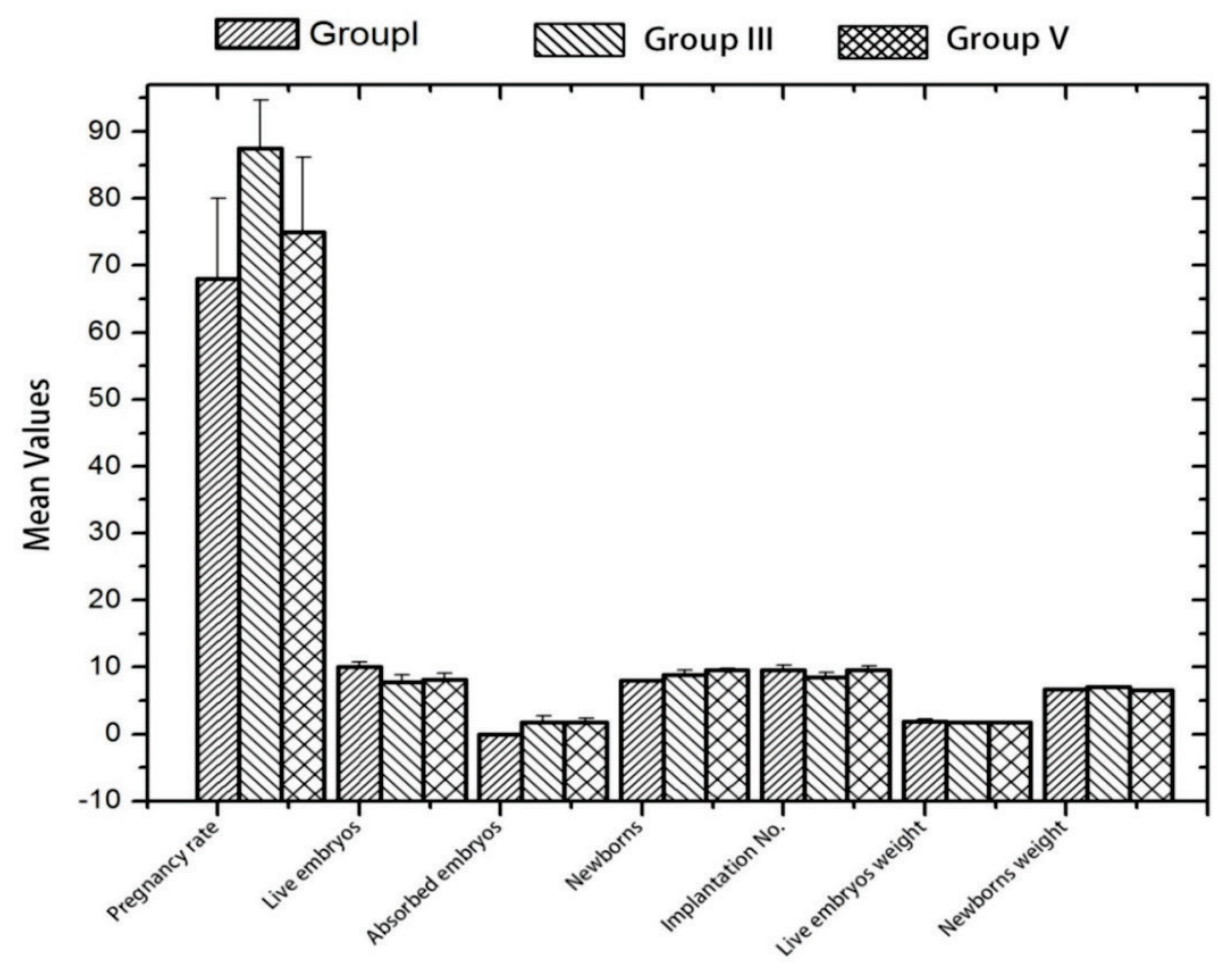

Fig. 1. Effect of light/darkness cycle on the embryos characteristics and implantation sites after mating with experimental males. 
Moreover, Table 4 showed that the change in lighting period leads to increase in the concentration level of melatonin hormone in rat blood serum from $2.4 \pm 0.2$ in GI to $44.5 \pm 3.5$ in GIII and then decreased to $33.0 \pm 8.0$ in $\mathrm{GV}$ with increasing lighting period (18 h light:6 h darkness). While, the testosterone concentration level was not different significantly with decrease the light period from $12 \mathrm{~h}$ in GI to $6 \mathrm{~h}$ light in GIII, but decreased to $2.6 \pm 0.1$ with maximum period of light in GV (18 h light). Then, the concentrations of hormones were increased with decrease the light period and down with increase the light period. In addition to, results in Figure 1 showed that there is no any significant difference between GI, GIII and GV concerning with embryo and newborn characteristics and implantation sites number.

\section{Effect of melatonin}

Body and testes weight were not significant at $\mathrm{P} \leq 0.05$ between all experimental groups (Fig. 2). Similar results were obtained for sperm characteristics as showed in Fig. 3A, when comparing GI with GII and GV with GVI. As the same results, were found between GIII and GIV for mean values of total number sperm and dead sperm (Fig. 3A). On the other hand, significant difference $(\mathrm{P} \leq 0.05)$ between the GIII and GIV was found with respect to normal and abnormal sperm movement trait (Fig. 3B). Melatonin treatment showed a positive impact on the melatonin and testosterone hormones level in the blood serum as showed in Table 5, where very highly significant difference was found between the GI and GII, GIII and GIV, GV and GVI, with the exception of melatonin level between GV and GVI. Figure 4A, B and $\mathrm{C}$ showed that embryos characteristics and implantation site traits were not significantly affected by treatment with melatonin. While, the mean values of the life new born weight and absorbed embryos characteristics showed significant differences between GI and GII (Fig. 4A).

Table 4. Effect of light/darkness cycle on the melatonin and testosterone hormones level $(\mathrm{pg} / \mathrm{ml})$ in the serum.

\section{Traits}

Treatment groups
Melatonin hormone

$\begin{array}{lcc}\text { Group I (GI) } & 2.4 \pm 0.2^{\mathrm{a}} & 5.4 \pm 0.2^{\mathrm{b}} \\ \text { Group III }(G I I I) & 44.5 \pm 3.5^{\mathrm{b}} & 5.6 \pm 0.2^{\mathrm{b}} \\ \text { Group V }(G V) & 33.0 \pm 8.0^{\mathrm{b}} & 2.6 \pm 0.1^{\mathrm{a}}\end{array}$

Testosterone hormone

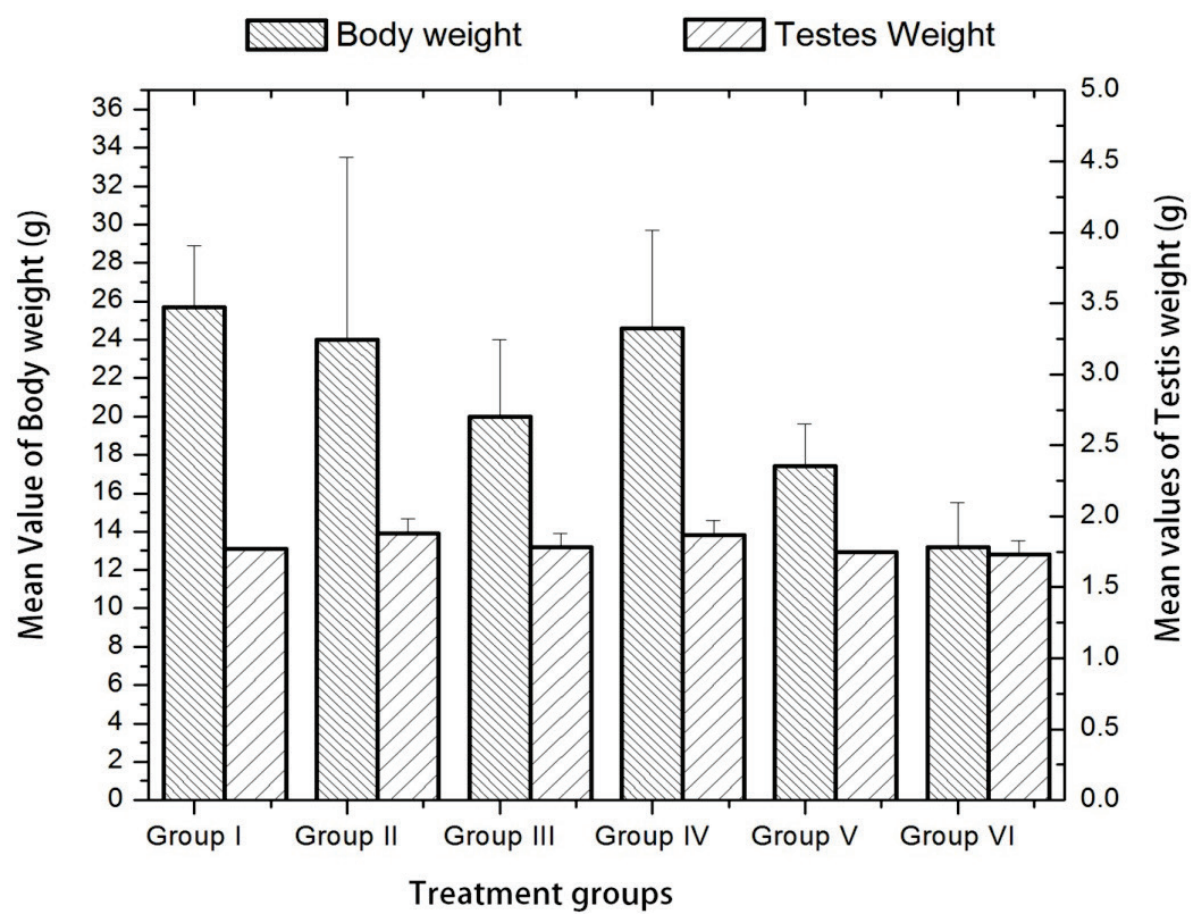

Fig. 2. Effect of exogenous melatonin treatment on the acquired body and testes weight $(\mathrm{g})$ compared with untreated groups for each light/darkness cycle alone. 


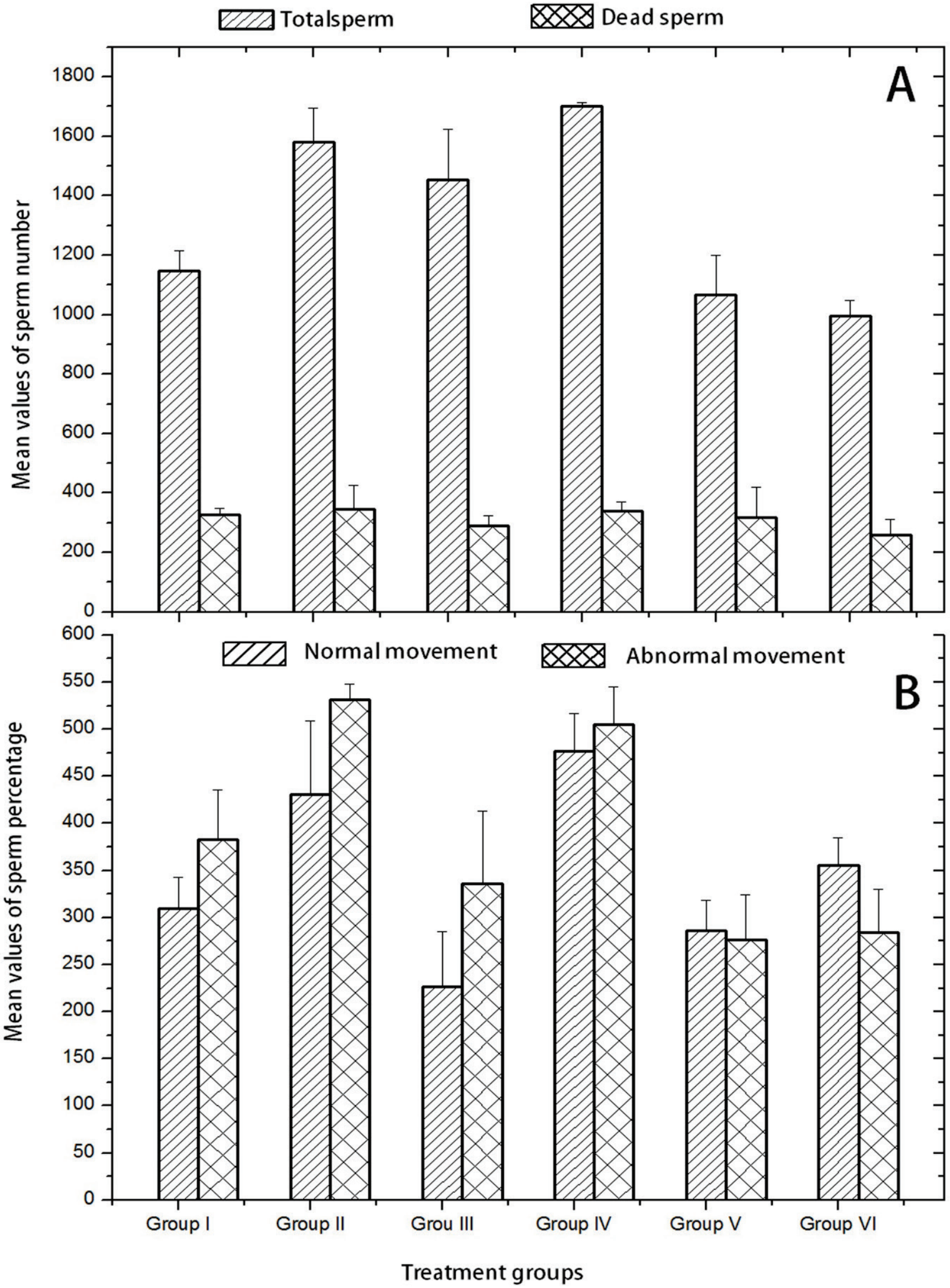

Fig. 3. Mean values of sperm characteristic in groups treated with exogenous melatonin compared to untreated groups in each light/darkness cycle alone. 


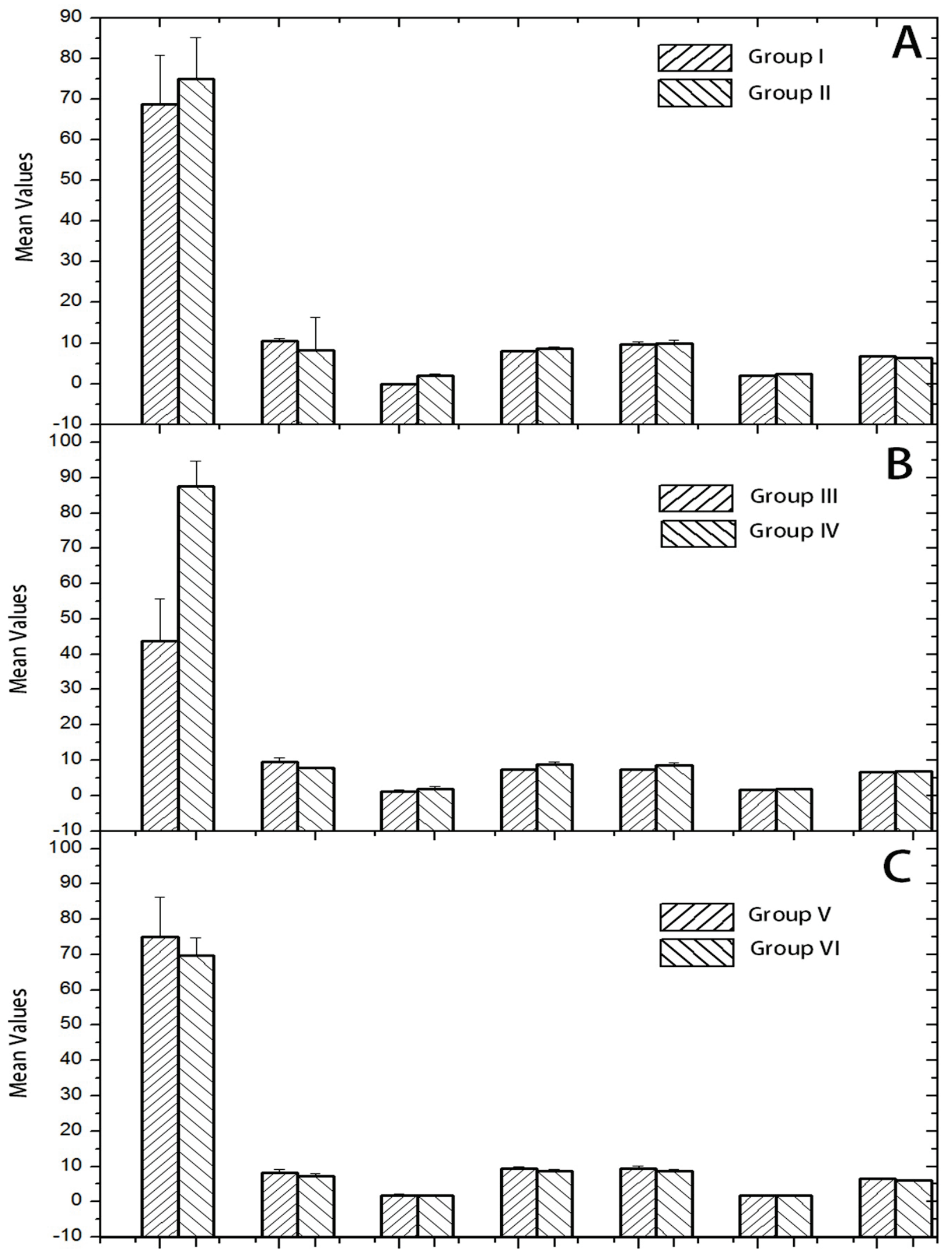

Pregnancy rate Live embryos
Absorbed embryos Newborns Implantation No. Characteristics

Fig. 4. Effects of melatonin injection on the embryo and newborns characteristics and implantation sites in groups for each light/darkness cycle alone. 
Table 5. Effect of exogenous melatonin treatment on the melatonin and testosterone hormones level $(\mathrm{pg} / \mathrm{ml})$ in the serum.

\begin{tabular}{lcc}
$\begin{array}{l}\text { Traits } \\
\text { Treatment groups }\end{array}$ & Melatonin hormone & Testosterone hormone \\
\hline Group I (GI) & $2.4 \pm 0.2^{\mathrm{a}}$ & $5.4 \pm 0.2^{\mathrm{a}}$ \\
Group II (GII) & $48.8 \pm 6.7^{\mathrm{b}}$ & $8.7 \pm 0.2^{\mathrm{b}}$ \\
Group III (GIII) & $44.5 \pm 3.5^{\mathrm{b}}$ & $5.6 \pm 0.2^{\mathrm{b}}$ \\
Group IV $(G I V)$ & $20.9 \pm 1.5^{\mathrm{a}}$ & $2.6 \pm 0.2^{\mathrm{a}}$ \\
Group V $(G V)$ & $33.0 \pm 8.0$ & $2.6 \pm 0.1^{\mathrm{a}}$ \\
Group VI $(G V I)$ & $37.2 \pm 4.1$ & $7.9 \pm 0.3^{\mathrm{b}}$ \\
\hline
\end{tabular}

\section{Discussion}

The results of this study showed that the sperm, embryos and newborns characteristics, testis weight and implantations sites were not affected by changing photoperiods. While, body weight increased in the third and fifth groups. However, we have found an increase in the total number of sperm, pregnancy rate, number and weight of live newborns in the third group, but this increment was not significant when compared to GI. The same result when compared the GV with GI for pregnancy rate, live newborns and the normal sperm movement. The effect of photoperiod and seasonal variations on reproductive in different animals was studied by many researches (Delgadillo et al. 1993, Kozdrowski and Dubiel 2004, de Ambrogi et al. 2006, Enciso et al. 2006, López-Fernández et al. 2007, Knecht et al. 2013, Petrocelli et al. 2015, Lourdes et al. 2015). Earlier works on F344 and BN male rats showed decrease in reproductive and body mass by short photoperiod (Heideman and Sylvester 1997, Lorincz et al. 2001). Also, Olayaki et al. (2008) showed that there was significant reduction in reproductive organ mass, viability, counts, and sperm motility when rats were exposed to short photoperiod. On the other hand, Ben Saad and Maurel (2002) reported that short photoperiod has an improvement effect on male reproductive characteristics in wild rabbits. Moreover, long photoperiod resulted in non-significant increase in sperm properties, but it increased the testis weight (Olayaki et al. 2008). This result disagree with Petrocelli et al. (2015), who showed that long photoperiod has significantly effect on the sperm concentration. Also, this result disagreed with results of Bagher et al. (2014) who mentioned that melatonin could improve the sperm motility. These results agreed with previous reports by
Ciereszko et al. (2000), Sancho et al. (2004) and (2006). Moreover, results of many studies agreed with our results in this study. It was reported that melatonin has no effect on sperm properties as these studies have shown that there is no relationship between the number of sperm and melatonin treatment (Casao et al. 2010, da Silva et al. 2011, Martín-Hidalgo et al. 2011, Ortiz et al. 2011). The body weight was higher during spring season than other seasons and plasma testosterone was higher during autumn and summer than during winter and spring (Lourdes et al. 2015). On the other side, our results agreed with Karakas and Gündüz (2003) and Bagher et al. (2014) who found that melatonin had no effect of the body weight. Although, there are some works indicated the melatonin may be able to affect energy intake and showed a decrease in the body weight (Marcon et al. 2008). The results of our study may be explained due to the increase melatonin in the rat serum in the third and fifth groups, and increased testosterone in the first and third groups only. Melatonin works as regulators for reproductive function in mammals through inhibitory action on melatonin receptors in the anterior pituitary gland, reproductive organs, and hypothalamus as described by Zemkova and Vanecek (1997), Balik et al. (2004), Soares et al. (2003) and Frungier et al. (2005). In addition, Heterosis may be affecting the reproductive characteristics (Smital 2009). The current results showed that serum testosterone was significantly higher in GII and GVI when compared with their control, while, the concentration of the same hormone was reduced significantly in GIII. Sarbast et al. (2013) and Kus et al. (2002) supported these results. The difference in the concentration of testosterone may refer to the relationship between the melatonin, photoperiod and gonadotropin releasing hormone $(\mathrm{GnRH})$ secreted from pituitary gland. Where, secretion of Luteinizing hormone (LH) and 
GnRH was affected by melatonin administration (Valenti et al. 1997, Valenti et al. 1999).

\section{Conclusions}

The present study indicated that the light/darkness cycle affect the body weight and melatonin and testosterone hormones, but not have any significant effect on the sperm and embryos characteristics, testes weight, pregnancy rate and implantation sites. Moreover, treatment with exogenous melatonin resulted in increase of melatonin and testosterone hormones concentration in case exposed rats to 12 and $18 \mathrm{~h}$ light only, but not significantly affect all other characteristics.

\section{Conflict of Interest}

There is no conflict of interest.

\section{Acknowledgements}

The authors would like to extend their sincere appreciation to the Deanship of Scientific Research at king Saud University for its funding this Research group NO (RGP-1438-058).

\section{References}

ALABBASSI MG, HUSSAIN SA, ALI SH: Therapeutic effects of melatonin in Lead-induced toxicity in rats. Iraqi J Pharm Sci 17: 47-54, 2008.

AXNER E, LINDE FC: Sperm morphology in the domestic cat, and its relation with fertility: a retrospective study. Reprod Dom Anim 2: 282-291, 2007.

BAGHER M, ARDESHIR M, SAEED S, MEHRYAR HR, TAGHI G, FATEMEH M, MOHAMMAD B: Melatonin improve the sperm quality in forced swimming test induced oxidative stress in nandrolone treated Wistar rats. Acta Med Iran 52: 496-504, 2014.

BALIK A, KRETSCHMANNOVÁ K, MAZNA P, SVOBODOVÁ I, ZEMKOVA H: Melatonin action in neonatal gonadotrophs. Physiol Res 53: 153-166, 2004.

BEN-SAAD MM, MAUREL DL: Long-day inhibition of reproduction and circadian photogonadosensitivity in Zembra Island wild rabbits (Oryctolagus cuniculus). Biol Reprod 66: 415-420, 2002.

BLOTTNER S, JEWGENOW K: Moderate seasonality in testis function of domestic cat. Reprod Domest Anim 42: 536-540, 2007.

BORG KE, LUNSTRA DD, CHISTENSON RK: Semen characteristics, testicular size, and reproductive hormone concentration in mature Duroc, Meishan, Fengjing, and Minzhu boars. Biol Reprod 49: 515-521, 1993.

BROEKHUIJSE MLWJ, ŠOŠTARIĆ E, FEITSMA H, GADELLA BM: The value of microscopic semen motility assessment at collection for a commercial artificial insemination center, is prospective study on factors explaining variation in pig fertility. Theriogenology 77: 1466-1479, 2012.

CASAO A, MENDOZA N, PÉREZ-PÉ R, GRASA P, ABECIA JA, FORCADA F, CEBRIÁN-PÉREZ JA, MUINO-BLANCO T: Melatonin prevents capacitation and apoptotic-like changes of ram spermatozoa and increases fertility rate. $J$ Pineal Res 48: 39-46, 2010.

CHABRA A, SHOKRZADEH M, NAGHSHVAR F, SALEHI F, AHMADI A: Melatonin ameliorates oxidative stress and reproductive toxicity induced by cyclophosphamide in male mice. Hum Exp Toxicol 33: 185-195, 2014.

CIERESZKO A, OTTOBRE JS, GLOGOWSKI J: Effects of season and breed on sperm activity and semen quality of boars. Anim Reprod Sci 64: 89-96, 2000.

DA SILVA CM, MACÍAS-GARCÍA B, MIRÓ-MORÁN A, GONZÁLEZ-FERNÁNDEZ L, MORILLO-RODRIGUEZ A, ORTEGA-FERRUSOLA C, GALLARDO-BOLAÑOS JM, STILWELL G, TAPIA JA, PEÑA FJ: Melatonin reduces lipid peroxidation and apoptotic like changes in stallion spermatozoa. $J$ Pineal Res 51: 172-179, 2011.

DE AMBROGI M, SPINACI M, GALEATI G, TAMANINI C: Viability and DNA fragmentation in differently sorted boar spermatozoa. Theriogenology 66: 1994-2000, 2006.

DELGADILLO JA, CHEMINEAU P: Abolition of the seasonal release of luteinizing hormone and testosterone in Alpine male goats (Capra hircus) by short photoperiodic cycles. J Reprod Fertil 94: 45-55, 1992. 
DELGADILlO JA, FLORES JA, VÉLIZ FG, POINDRON P, PÉREZ-VILLANUEVA JA, MARTÍNEZ DE LA ESCALERA G: Photoperiodic treatment of bucks markedly improves the response of seasonally ovulatory goats to the male effect. In: Proceedings of the 7th International Conference on Goats. Agricultural Research and Extension Programs, Tours, 2000, pp 396-399.

DELGADILLO JA, LEBOEUF B, CHEMINEAU P: Maintenance of sperm production in bucks during a third year of short photoperiodic cycles. Reprod Nutr Dev 33: 609-617, 1993.

DIXIT AS, SINGH NS: Photoperiod as a proximate factor in control of seasonality in the subtropical male tree sparrow, Passer montanus. Front Zool 8: 1, 2011.

DONMEZ N, KARACA F, BELGE F, ATES CT: The effects of melatonin application on some haematological parameters and thyroid hormones and testosterone in male goats' non-breeding season. Veterinarski Arhiv 74: 281-287, 2004.

DUBBELS R, REITER RJ, KLENKE E, GOEBEL A, SCHNAKENBERG E, EHLERS C, SCHIWARA HW, SCHLOOT W: Melatonin in edible plants identified by radioimmunoassay and by high performance liquid chromatography-mass spectrometry. J Pineal Res 18: 28-31, 1995.

ENCISO M, LÓPEZ-FERNÁNDEZ C, FERNÁNDEZ JL, GARCÍA P, GOSÁLVEZ A, GOSÁLVEZ J: A new meted to analyze boar sperm DNA fragmentation under bright-field or fluorescence microscopy. Theriogenology $\mathbf{6 5}$ : 308-316, 2006.

ESPINO J, BEJARANO I, ORTIZ A, LOZANO GM, GARCÍA JF, PARIENTE JA, RODRÍGUEZ AB: Melatonin as a potential tool against oxidative damage and apoptosis in ejaculated human spermatozoa. Fertil Steril 94: 1915-1917, 2010.

FAVRE NR, BONAURA MC, TITTARELLI CM, MANSILLA HD, DE LA SOTA RL, STORNELLI MA: Effect of natural photoperiod on epididymal sperm quality and testosterone serum concentration in domestic cat (Felis catus). In: Proceedings of the 7th Quadrennial International Symposium on Canine and Feline Reproduction. International Veterinary Information Service, Whistler, 2012.

FRUNGIER MB, MAYERHOFER A, ZITTA K, PIGNATARO OP, CALANDRA RS, GONZALEZ-CALVAR SI: Direct effect of melatonin on Syrian hamster testes: melatonin subtype 1a receptors, inhibition of androgen production, and interaction with the local corticotropin-releasing hormone system. Endocrinology 146: 1541-1552, 2005.

GALANO A, TAN DX, REITER RJ: Melatonin as a natural ally against oxidative stress: a physicochemical examination. J Pineal Res 51: 1-16, 2011.

GOLDMAN BD: Parameters of the circadian rhythm of pineal melatonin secretion affecting reproductive responses in Siberian hamsters. Steroids 56: 218-225, 1991.

HARDELAND R, BALZER I, POEGGELER B, FUHRBERG B, URÍA H, BEHRMANN G, WOLF R, MEYER TJ, REITER RJ: On the primary functions of melatonin in evolution: Mediation of photoperiodic signals in a unicell, photooxidation, and scavenging of free radicals. J Pineal Res 18: 104-111, 1995.

HAZLERIGG DG, WAGNER GC: Seasonal photoperiodism in vertebrates: from coincidence to amplitude. Trends Endocrinol Metab 17: 83-91, 2006.

HEIDEMAN PD, SYLVESTER CJ: Reproductive photoresponsiveness in unmanipulated Fischer 344 laboratory rats. Biol Reprod 57: 134-138, 1997.

HOTZEL MJ, WALKDEN-BROWN SW, FISHER JS, MARTIN GB: Determinants of the annual pattern of reproduction in mature male Merino and Suffolk sheep: responses to a nutritional stimulus in the breeding and non-breeding seasons. Reprod Fertil Dev 15: 1-9, 2003.

KARAKAS A, GÜNDÜZ B: Melatonin implants have no effect on the testis volume and body weight in Mongolian gerbils. Turk J Biol 27: 209-214, 2003.

KNECHT D, ŚRODOŃ S, SZULC K, DUZIŃSKI K: The effect of photoperiod on selected parameters of boar semen. Livest Sci 57: 364-371, 2013.

KOZDROWSKI R, DUBIEL A: The effect of season on the properties of wild boar (Sus scrofa L.) semen. Anim Reprod Sci 80: 281-289, 2004.

KUS I, AKPOLAT N, OZEN OA, SONGUR A, KAVAKLİ A, SARSĮLMAZ M: Effects of melatonin on Leydig cells in pinealectomized rat: an immunohistochemical study. Acta Histochem 104: 93-97, 2002. 
LAMPIAO F, PLESSIS S: New developments of the effect of melatonin on reproduction. World J Obstet Gynecol 10: $15-22,2013$.

LEBOUEF B, RESTALL B, SALAMON S: Production and storage of goat semen for artificial insemination. Anim Reprod Sci 62: 113-141, 2000.

LERNER AB, CASE JD, HEINZELMAN RV: Structure of Melatonin. J Am Chem Soc 81: 6084-6085, 1959.

LEVINE RJ, MATHEW RM, CHENAULT CB, BROWN MH, HURTT ME, BENTLEY KS, MOHR KL, WORKING PK: Differences in the quality of semen in outdoor workers during summer and winter. $N$ Engl J Med 323: 12-16, 1990.

LÓPEZ-FERNÁNDEZ C, CRESPO F, ARROYO F, FERNÁNDEZ JL, ARANA P, JOHNSTON SD, GOSÁLVEZ J: Dynamics of sperm DNA fragmentation in domestic animals II. The stallion. Theriogenology 68: 1240-1250, 2007.

LORINCZ AM, SHOEMAKER MB, HEIDEMAN PD: Genetic variation in photoperiodism among naturally photoperiodic rat strains. Am J Physiol Integr Reg Physiol 281: R1817-R1824, 2001.

LOURDES GC, CAROLINA GM, JULIAN SM, JOSÉ LG, LUIS AZ: Seasonal changes in reproductive activity, sperm variables and sperm freezability in Blanca Andaluza bucks. Span J Agric Res 13: e0403, 2015.

MARCON L, HALES BF, ROBAIRE B: Reversibility of the effects of subchronic exposure to the cancer chemotherapeutics bleomycin, etoposide, and cisplatin on spermatogenesis, fertility, and progeny outcome in the male rat. $J$ Androl 29: 408-417, 2008.

MARTÍN-HIDALGO D, BARÓN FJ, BRAGADO MJ, CARMONA P, ROBINA A, GARCÍA-MARÍN LJ, GIL MC: The effect of melatonin on the quality of extended boar semen after long-term storage at $17^{\circ} \mathrm{C}$. Theriogenology 75: 1550-1560, 2011.

MISRA M, RANI S, SINGH S, KUMAR V: Regulation of seasonality in the migratory male black headed bunting (Emberiza melanocephala). Reprod Nurt Dev 44: 341-352, 2004.

MUKHERJEE A, HALDAR C: Photoperiodic regulation of melatonin membrane receptor (MT1R) expression and steroidogenesis in testis of adult golden hamster, Mesocricetus auratus. $J$ Photochem Photobiol B 140: 374-380, 2014.

OLAYAKI LA, SOLADOYE AO, SALMAN TM, JORAIAH B: Effects of photoperiod on testicular functions in male Sprague-Dawley rats. Nigerian J Physiol Sci 23: 27-30, 2008.

OOI VE, NG TB: Histological studies on the effects of pineal 5-methoxyindoles on the reproductive organs of the male golden hamster. $J$ Pineal Res 7: 315-324, 1989.

ORTIZ A, ESPINO J, BEJARANO I, LOZANO GM, MONLLOR F, GARCÍA JF, PARIENTE JA, RODRÍGUEZ AB: High endogenous melatonin concentrations enhance sperm quality and short term in vitro exposure to melatonin improves aspects of sperm motility. J Pineal Res 50: 132-139, 2011.

PERDOMO J, CABRERA J, ESTEVEZ F, LORO J, REITER RJ, QUINTANA J: Melatonin induces apoptosis through a caspase dependent but reactive oxygen species-independent mechanism in human leukemia Molt-3 cells. J Pineal Res 55: 195-206, 2013.

PESCHKE E, FRESE T, CHANKIEWITZ E, PESCHKE D, PREISS U, SCHNEYER U, SPESSERT R, MÜHLBAUER E: Diabetic Go to Kakizaki rats as well as type 2 diabetic patients show a decreased diurnal serum melatonin level and an increased pancreatic melatonin-receptor status. $J$ Pineal Res 40: 135-143, 2006.

PETROCELLI H, CARLOS B, JAIME G: Seasonal variation in sperm characteristics of boars in southern Uruguay. R Bras Zootec 44: 1-7, 2015.

POPWELL JM, FLOWERS WL: Variability in relationships between semen quality and estimates of in vivo and in vitro fertility in boars. Anim Reprod Sci 81: 97-113, 2004.

RANI S, KUMAR V: Photoperiod regulation of seasonal reproduction in higher vertebrates. Indian J Exp Biol 52: 413-419, 2014.

ROCHA CS, RATO L, MARTINS AD, ALVES MG, OLIVEIRA PF: Melatonin and male reproductive health: relevance of darkness and antioxidant properties. Curr Mol Med 15: 1-13, 2015.

RUIZ-SÁNCHEZ AL, O'DONOGHUE R, NOVAK S, DYCK MK, COSGROVE JR, DIXON WT, FOXCROFT GR: The predictive value of routine semen evaluation and IVF technology for determining relative boar fertility. Theriogenology 66: 736-748, 2006. 
SANCHO S, PINART E, BRIZ M, GARCIA-GIL N, BADIA E, BASSOLS J, KÁDÁR E, PRUNEDA A, BUSSALLEU E, YESTE M, COLL MG, BONET S: Semen quality of postpubertal boars during increasing and decreasing natural photoperiods. Theriogenology 62: 1271-1282, 2004.

SANCHO S, RODRÍGUEZ-GIL JE, PINART E, BRIZ M, GARCÍA-GIL N, BADIA E, BASSOLS J, PRUNEDA A, BUSSALLEU R, YESTE M, CASA I, PALOMO MJ, RAMIÓ L, BONET S: Effects of exposing boars to different artificial light regimens on semen plasma markers and "in vivo" fertilizing capacity. Theriogenology 65: 317-331, 2006.

SARBAST AM, ALMAS MRM: Physiological effects of melatonin on leptin, testosterone and biochemical parameters in Albino rats. IOSR J Pharm 3: 48-53, 2013.

SELLÉS E, GADEA J, ROMAR R, MATÁS C, RUIZ S: Analysis of in vitro fertilizing capacity to evaluate the freezing procedures of boar semen and to predict the subsequent fertility. Reprod Domest Anim 38: 66-72, 2003.

SHARON T, VAN DER HORST G, MORTIMER D: The future of computer-aided sperm analysis. Asian J Androl 17: $545-553,2015$.

SMITAL J: Effects influencing boar semen. Anim Reprod Sci 110: 335-346, 2009.

SOARES JM, MASONA MI, ERASHIN C, DUBOCOVICH ML: Functional receptors in rats' ovaries at various stages of the estrous cycle. J Pharmacol Exp Ther 306: 694-702, 2003.

SOGORESCU E, ZAMFIRESCU S, ROSOIU N, ANGHEL A, NADOLU D: Seasonal variations of plasma testosterone levels and testicular volume in Carpathian bucks. Afri J Agric Res 6: 6735-6740, 2011.

SOGORESCU E, ZAMFIRESCU S, ANGHEL A, NADOLU D, DOBRIN N.: Pattern of testosterone secretion, testicular volume and sperm production after applied the photoperiod treatments on Carpathian bucks. Ann Rom Soc Cell Biol 17: 284-291, 2012.

STEFULJ J, HÖRTNER M, GHOSH M, SCHAUENSTEIN K, RINNER I, WÖLFLER A, SEMMLER J, LIEBMANN PM: Gene expression of the key enzymes of melatonin synthesis in extrapineal tissues of the rat. $J$ Pineal Res 30: 243-247, 2001.

TILDEN AR, BECKER MA, AMMA LL, ARCINIEGA J, MCGAW AK: Melatonin production in an aerobic photosynthetic bacterium: an evolutionarily early association with darkness. J Pineal Res 22: 102-106, 1997.

VALENTI S, GIUSTI M, GUIDO R, GIORDANO G: Melatonin receptors are present in adult rat Leydig cells and are coupled through a pertussis toxin sensitive G-protein. Eur J Endocrinol 136: 633-639, 1997.

VALENTI S, THELLUNG S, FLORIO T, GIUSTI M, SCHETTINI G, GIORDANO G: A novel mechanism for the melatonin inhibition of testosterone secretion by rat Leydig cells: reduction of GnRH-induced increase in cytosolic $\mathrm{Ca}^{2+}$. J Mol Endocrinol 23: 299-306, 1999.

VITALINI S, GARDANA C, SIMONETTI P, FICO G, IRITI M: Melatonin, melatonin isomers and stilbenes in Italian traditional grape products and their antiradical capacity. J Pineal Res 54: 322-333, 2013.

ZEMKOVA H, VANECEK $\mathrm{J}$ : Inhibitory effect of melatonin on gonadotropin-releasing hormone-induced $\mathrm{Ca}^{2+}$ oscillations in pituitary cells of newborn rats. Neuroendocrinology 165: 276-283, 1997. 